\title{
PRESENTATION OF THE CULTS OF SOVIET LEADERS IN EDUCATIONAL INSTITUTIONS OF THE CENTRAL BLACK EARTH REGION IN 1928-1934
}

\author{
Andrey Zlobin \\ Candidate of Historical Sciences, Associate Professor, Voronezh State University of Engineering \\ Technologies, Revolution street,19, Voronezh, Russia, E-mail: anzlobin@bk.ru
}

\begin{abstract}
The article examines the presentation of the personality cults of the Soviet leaders in the educational institutions of the Central Black Earth Region. The article analyzes the influence of mass public discussions in relation to Stalin's article in the journal "Proletarian Revolution", which took place, among other things, among the pedagogical environment. The work touches upon aspects related to the introduction of new ideologically rich curricula into the educational process and to the propaganda of the cults of other Soviet leaders. The source base of the study is primarily the materials of the State Archive of Socio-Political History of the Voronezh Region (GAOPI VO) and the State Archive of the Voronezh Region (GAVO). In the conclusion, it is emphasized that despite the intensified propaganda of communist ideological attitudes, a significant part of the teaching staff continued to treat the Soviet leaders critically, and the student youth, although they perceived Soviet values in large part, remained socially and ideologically not homogeneous.
\end{abstract}

Keywords: ideology, propaganda, personality cult, school, leaders, education.

\section{INTRODUCTION}

Party ideologists considered the upbringing of a new person loyal to the Soviet regime and devoted to communist ideas to be a necessary condition for ensuring the stability of the Soviet system and building a communist society in the future. Ideological propaganda in the 30s covered all strata of Soviet society and all age groups, including teachers and students.

Party propaganda and communist education were an important part of the activities of the Soviet school, and the cults of the ruling leaders were an important part of communist agitation. In the scientific literature of the Soviet period, issues of communist education and ideology were considered in the context of general problems and trends in the development of education, through the prism of the implementation of party educational programs.

\section{DISCUSSION AND RESULTS}

In the historical literature, the opinion has strengthened that after the celebration of the 50th anniversary of the demonstration of the Stalinist image, there is a long break until the plenum of the Central Committee in January 1933, Jan Plamper writes: "This powerful start was followed by a three and a half year pause ... By mid-1933 years, the cult of Stalin finally acquired a mass character ... ". The researcher notes that "from 1930 to mid-1933. Stalin appears on the pages of Pravda very rarely, and only together with other party functionaries, not standing out in any way from their number, and these appearances are in no way tied to socialist holidays. " With the thesis about a break in the propaganda of the personality cult between December 1929 and January 1933. it is impossible to agree. Stalin's relatively rare appearance on the pages of official grief was compensated by the deployment of his image as the one-man and infallible leader through other public channels. One of these channels, which presented the image of the new leader to society, was the mass public discussions initiated by the party bodies about Stalin's article in the journal 
Proletarskaya Revolyutsiya (№. 6, 1931) and the so-called "6 conditions of comrade. Stalin ", which were formulated by him on June 23, 1931 in a speech at a meeting organized by the Central Committee of the AllUnion Communist Party of Bolsheviks for representatives of economic organizations. (Briefly, Stalin's conditions can be formulated as follows: 1 . To recruit labor force in an organized manner in the order of agreements with collective farms, to mechanize labor. 2. To eliminate labor turnover, to eliminate leveling, to organize wages correctly, to improve the living conditions of workers. 3. To eliminate depersonalization, improve organization 4. To ensure that the working class of the USSR has its own production and technical intelligentsia. 5. To change the attitude towards the engineering and technical forces of the old school, to show them more attention and care, to more boldly involve them in work 6 . Introduce and strengthen cost accounting, raise intraindustrial accumulation). The speech was published in the Pravda newspaper on July 5,1931 , then it was reprinted many times.

An article in a party magazine criticized Slutsky's article "The Bolsheviks on German Social Democracy in the Period of Its Prewar Crisis," which questioned Lenin's position on the assessment of prewar German Social Democracy. Stalin declares the impossibility of discussing Lenin's legacy, declaring it an axiom, at the end of the article he calls: "to raise questions of the history of Bolshevism to the proper level, to put the study of the history of our party on a scientific, Bolshevik track and to sharpen our attention against Trotskyist and any other falsifiers of history our party, systematically tearing off their masks. This is all the more necessary because even some of our historians - I am talking about historians without quotation marks, about the Bolshevik historians of our party - are not free from mistakes that pour water on the mill of the Slutskys and Volosevichs. " (P.21) Party agitators, in fact, received permission from the leader to write for a mass audience, I focus on the contribution, heroism and merits of the party leaders. According to a special decision of the Regional Committee of the All-Union Communist Party (Bolsheviks), the study of Stalin's letter began synchronously in all areas of the Central Black Earth Region. The massive study of the letter began in December 1931 and lasted for the first months of 1932. In a number of large districts (Kursk, Tambov), the study of the letter began only with the arrival of speakers from the Regional Committee. The main forms of elaboration of the letter in most districts included: the presentation of reports on the letter at the Bureau, the plenum of the RK and RKK, district activists, cells, meetings of workers and collective farmers, teachers' conferences, a network of party inquiries, etc., the issuance of detailed political resolutions.

The main mass of party members, Komsomol activists, workers, collective farmers, teachers were involved in the campaign to work out the letter. Most speeches and adopted resolutions emphasized the enormous political, theoretical and historical significance of Stalin's article "not only for the USSR, but for the entire Communist International, for the cause of the international proletarian revolution." The VSU teacher Militsin used the textbook of Friedland and Slutsky in the course "History of the West and the Peoples of the USSR" and "did not reflect at all the letters of Comrade Stalin. The program on the history of the class struggle, reworked already on the basis of the instructions of Comrade Stalin, did not reflect the most important issue the growth of the bourgeois revolution into a socialist one, the role of Bolshevism in the struggle against opportunism and centrism in the international labor movement is not expressed. In addition, the study of the letter led to an accelerated revision of the curriculum. For example, at the Voronezh Pedagogical Institute from January 1, 32. 15 diaries were announced for checking and working out the programs, during which they were supplemented with questions of a methodological nature.

The ideological component was contained in the new educational programs not only in social studies and history, but also in all other disciplines of the school curriculum from the first to the last grade. Communist ideology was introduced into the consciousness of schoolchildren along several semantic lines at once: antireligious education, propaganda of proletarian internationalism, glorification of the revolutionary past, praise of the achievements and prospects of the Soviet system and leaders (primarily I.V. Stalin) as organizers of victories and successes. The history course was built mainly around themes dedicated to the glorification of the revolutionary past, the class struggle at different stages of history in different countries. In social studies classes in high school, the speeches and speeches of I.V. Stalin, including the speech "On work in the countryside" and a speech at the congress of collective farmers shock workers. On the one hand, this linked the theoretical course with modern political events, on the other hand, it helped to consolidate in the minds of high school students the ideologies associated with the growing cult of the leader's personality. In addition to the Stalin cult, regional propaganda formed stable hypertrophied images of a number of other Soviet leaders and statesmen. First of all, the head of the regional party organization I.M. Vareikis, and a colleague of the leader L.M. Kaganovich, who in 1919 was sent to the Voronezh sector of the Southern Front, and after the capture of the city by the Bolsheviks was the chairman of the Voronezh Gubrevkom, and then the Gubispolkom. In honor of Kaganovich, the Voronezh city Central Park was named in 1929, and in 1936 the 
city district. Three more Voronezh districts bore the names of Vareikis, Voroshilov and Stalin. Here are a few buildings and excerpts from the speeches of the delegates of the conference, characterizing the new status of the chief communist of the region.

"Long live our close-knit regional party organization, headed by our beloved I.M. Vareikis ". "We are happy that we have the opportunity to greet losif Mikhailovich together with you as one of the most tireless and outstanding fighters for transforming the Central Black Earth Region from a backward region into an advanced region of our country. Professor Silin, on behalf of the scientific workers, noted: "in our area the successes and merits achieved in this five-year period by Comrade Vareikis are especially close. We saw how he built our Central Black Earth Region before our very eyes ". As you can see, the first person of the Central Black Earth District is called by epithets: beloved, steering Bolshevik, talented commander, outstanding fighter, best student of Stalin, etc. His image in the regional formatting was a direct reflection of the Stalinist cult and was created in his image and likeness. The personality cult became an integral part of the country's political culture not only at the national level, but also on a regional scale.

\section{CONCLUSION}

Communist education certainly bore fruit. The seeds of these ideas fell on fertile soil, as they were in tune with the spirit of the times and the life sensations of the new generation. A significant part of the youth was imbued with the ideas of disinterested labor in the name of all mankind, shared the ideas of internationalism and Marxist ideology, believed in the leaders, was ready to become "in the gun" at the first call of the party and the Soviet government. At the same time, the Soviet youth did not represent a homogeneous mass.

The specific features of the Central Black Earth Region were: rapid urbanization associated with the influx of cities, in many respects embittered by the Soviet regime for the excesses of the collectivization of the population, and the huge, densely populated territory of the region, which caused the inability of the party, Soviet and punitive bodies to quickly cope with differences of opinion and critical assessments of the population. The main goal of communist education in Soviet educational institutions - the formation of a new person - was achieved with great difficulty, with numerous difficulties and failures. It was far from being a linear process with a pre-programmed positive outcome.

\section{REFERENCE LIST}

1. Bibanov T. P. (1971) Activity of the Communist Party for the development and improvement of schools of the RSFSR in 1929-1934. ... Candidate of Historical Sciences, Moscow. 20 p. (in Russ).

2. Koltsov A.V. (1960) Cultural construction in the RSFSR during the first five-year plan (1928-1932). M.-L.: Publishing House of the USSR Academy of Sciences 74 p. (in Russ).

3. Plyasovskikh V. S. (1987) The policy of the CPSU in the field of public education: the experience of development and implementation. M.. 454 p. (in Russ).

4. Lipchansky A.M. (2001) The formation of general mass school education in Russia during the period of socio-economic transformations: 1861-1941. Experience, lessons: autoref. dis. ... Doctor of Historical Sciences, Moscow. 30 p. (in Russ).

5. Anaikina L. I (2001). Party and state policy in the sphere of public education in the RSFSR (1922-1991): abstract of the dissertation. ... Doctor of Historical Sciences, Moscow. 25 p. (in Russ).

6. Daich Z. G. (1991) School policy in the USSR. Lessons of party-state leadership, prospects for development. Moscow: MPSU. 382 p. (in Russ).

7. Plumper Ya. (2010) The alchemy of power. The cult of Stalin in the visual arts. M. UFO. 496 p. (in Russ).

8. Heizer James L. (1977) The Cult o f Stalin, 1929-1939. P h. D. diss. University o f Kentucky. Pp. 65-68. (in Russ).

9. Chernova N. V. (2002) Escalation of the commander's myth of Stalin, 1929-1939. Problems of Russian history. №. 1. Pp. 372-386. (in Russ).

10. Buldakov V. P. (2017) From taming the dictate: Power and culture in the 1920s. Culture and power in the USSR. 1920-1950-ies: Materials of the IX International Scientific Conference. St. Petersburg, October 24-26, 2016-Moscow: Political Encyclopedia; Presidential Center of B. N. Yeltsin. Pp. 16-18. 
(in Russ).

11. Pavlova I. V. (2019) The mechanism of Stalinist power: formation and functioning, 1917-1941 [Electronic resource]. URL: https://profilib.net/chtenie/99732/ irina-pavlova-mekhanizm-stalinsky-vlastistanovlenie-i-funktsionirovanie-1917 - 1941-lib-88.php (date of request:12.09.2019) (in Russ).

12. Khlevnyuk O. V. (2010) Host. Stalin and the establishment of the Stalinist dictatorship. Moscow: ROSSPEN; Foundation of the First President of Russia B. N. Yeltsin. 479 p. (in Russ).

13. Medvedev R. (2017) To the court of history. About Stalin and Stalinism. M.: Litres. 1210 p. (in Russ).

14. Kara-Murza G. (2002) Soviet civilization. From the beginning to the Great Victory. Moscow: Eksmo: Algorithm. (in Russ).

15. Rolf M. M. (2011) The study of the Stalinist state of propaganda: cultural representations, customs and borrowings under Stalinism / / History of Stalinism: results and problems of study: materials of the International Scientific Conference, Moscow, December 5-7, 2008. Moscow: ROSSPEN: Foundation "Presidential Center of B. N. Yeltsin". Pp. 407-421. (in Russ).

16. Rolf M. (2009) Soviet mass holidays / translated from German by V. T. Altukhova. M.: ROSSPEN; Foundation of the first President of Russia B. N. Yeltsin. 439 p. (in Russ).

17. Brandenberger D. (2017) The crisis of Stalinist agitprop: Propaganda, political enlightenment and terror in the USSR, 1927-1941. M.: ROSSPEN. 367 p. (in Russ).

18. Pavlova I. V. (2001) The mechanism of power and the construction of Stalinist socialism. Novosibirsk: Publishing House of the SB RAS. 460 p. (in Russ).

19. Shalaeva N. V. (2013) Sovetskiy gosudarstvennyy prazdnik kak mekhanizm formirovaniya reprezentativnogo obraza vlasti i sotsiokulturnoy kommunikatsii [Soviet state holiday as a mechanism of formation of a representative image of power and socio-cultural communication]. 2013. №. 1. Pp. 132-136. (in Russ).

20. Igritsky Yu. I. (1990) The concept of totalitarianism: lessons of long-term discussions in the West. History of the USSR. 1990. №. 6. Pp. 172-190. (in Russ).

21. Early Soviet society as a social project, 1917-1930s: (2018) monograph: in 2 ch. Ch. 2: Soviet society: culture, consciousness, behavior / Collective author; under the general editorship of L. N. Mazur; M-in science and higher education. education, Ural. feder. univ. Yekaterinburg: Ural Publishing House. unta. 462 p. (in Russ).

22. Fitzpatrick Sh. (2008) Everyday Stalinism. Social history of Soviet Russia in the 30s: the city. 2nd ed. Moscow: ROSSPEN: Foundation of the First President of Russia B. N. Yeltsin. 336 p. (in Russ). 